\title{
New molecular evidence for fragmentation between two distant populations of the threatened stingless bee Melipona subnitida Ducke (Hymenoptera,Apidae, Meliponini)
}

\author{
Geice R. Silva', Bruno A. Souza², Fábia M. Pereira², \\ Maria T. R. Lopes², Sérgio E. S. Valente', Fábio M. Diniz²
}

I Department of Biological Sciences, Federal University of Piaui, CEP: 64049-550, Teresina, PI, Brazil 2 EMBRAPA Meio-Norte, Laboratory of Molecular Biology \& Biotechnology, CP: 01, CEP: 64.006-220, Teresina, PI, Brazil

Corresponding author: Fábio M. Diniz (fabio.diniz@embrapa.br)

Academic editor: Jack Neff | Received 18 February 2014 | Accepted 3 March 2014 | Published 12 June 2014

Citation: Silva GR, Souza BA, Pereira FM, Lopes MTR, Valente SES, Diniz FM (2014) New molecular evidence for fragmentation between two distant populations of the threatened stingless bee Melipona subnitida Ducke (Hymenoptera, Apidae, Meliponini). Journal of Hymenoptera Research 38: 1-9. doi: 10.3897/JHR.38.7302

\begin{abstract}
For a snapshot assessment of the genetic diversity present within Melipona subnitida, an endemic stingless bee distributed in the semi-arid region of northeastern Brazil, populations separated by over 1,000 $\mathrm{km}$ distance were analyzed by ISSR genotyping. This is a prerequisite for the establishment of efficient management and conservation practices. From 21 ISSR primers tested, only nine revealed consistent and polymorphic bands (loci). PCR reactions resulted in 165 loci, of which 92 were polymorphic $(57.5 \%)$. Both $\Phi_{S T}\left(\right.$ ARLEQUIN) and $\theta^{B}(\mathrm{HICKORY})$ presented high values of similar magnitude $(0.34, \mathrm{p}<0.0001$ and $0.33, \mathrm{p}<0.0001$, respectively), showing that these two groups were highly structured. The dendrogram obtained by the cluster analysis and the scatter-plot of the PCoA corroborate with the data presented by the AMOVA and $\theta^{\mathrm{B}}$ tests. Clear evidence of subdivision among sampling sites was also observed by the Bayesian grouping model analysis (STRUCTURE) of the ISSR data. It is clear from this study that conservation strategies should take into account the heterogeneity of these two separate populations, and address actions towards their sustainability by integrating our findings with ecological tools.
\end{abstract}

\section{Keywords}

Population differentiation, Hymenoptera, Jandaíra, genetic diversity, ISSR markers

Copyright Geice R. Silva et al. This is an open access article distributed under the terms of the Creative Commons Attribution License (CC BY 4.0), which permits unrestricted use, distribution, and reproduction in any medium, provided the original author and source are credited. 


\section{Introduction}

Melipona subnitida Ducke (Hymenoptera, Apidae, Meliponini) is an endemic stingless bee distributed in the Caatinga, the semi-arid region of northeastern Brazil (Michener 2007, Camargo and Pedro 2013). The species, called Jandaíra by natives, has great ecological significance as a pollinator of the local native flora and cultivated crops and is of economic importance in honey production, which is valued for its alleged medicinal properties and antibacterial activity (Cruz et al. 2004; Alves et al. 2008; Silva and Paz 2012).

The stingless bees are currently threatened by the increasing destruction of native semi-arid vegetation and by the intensification of agriculture in the Caatinga (Roulston and Goodell 2011; Pereira et al. 2011). In response, small populations of stingless bees may gradually decline, resulting in local extinction. The assessment of the genetic diversity present within Melipona subnitida populations is therefore a prerequisite for the establishment of efficient management and conservation practices.

Molecular markers have proven to be decisive in elucidating diversity and differences at the DNA level in microorganisms, plants and animals (Panwar et al. 2010; Sebastien et al. 2012; Rana et al. 2012; Bonatti et al. 2014). Among several markers, Inter Simple Sequence Repeats (ISSR) have been used due to their low cost and high level of polymorphism, and as an alternative to overcome reproducibility problems commonly found in other PCR-based markers (Abbot 2001; Lima-Brito et al. 2011). ISSRs are semiarbitrary markers based on DNA amplification by PCR in the presence of single 15- to 20-bp long primer complementary to a target short sequence repeat (Zietkiewicz et al. 1994). Despite the existence of few genetic studies related to stingless bees, it has recently been shown that ISSR markers can be useful in the analysis of natural bee populations, contributing to the development of management strategies of these important genetic resources (Nascimento et al. 2010; Tavares et al. 2013).

The present study uses ISSR analysis to investigate the degree of genetic differentiation between two Melipona subnitida populations separated by over $1,000 \mathrm{~km}$ in the Brazilian Caatinga.

Worker bees were randomly collected from natural colonies (one bee from each of 30 colonies) distributed in 2 locations only: (1) 15 nests in Natal (NAT; coordinates: $5^{\circ} 48^{\prime} 04^{\prime \prime S}, 35^{\circ} 11^{\prime} 08^{\prime \prime W}$; State of Rio Grande do Norte) and (2) 15 nests in Itha das Canárias, Parnaíba River Delta (PAR; coordinates: 246'39"S, 4151'59"W; on the border of the states of Piauí and Maranhão) in Brazil (Figure 1A). All the samples were taken to the laboratory and stored at $-20^{\circ} \mathrm{C}$ until further use. Total genomic DNA was extracted from each adult worker thorax using a phenol/chloroformalcohol isoamyl (25:24:1, v:v:v) extraction of SDS/proteinase-K digested tissue of each individual (Sambrook et al. 1989). High molecular weight DNA was isolated by ethanol precipitation and visualized by agarose gel electrophoresis.

The extracted DNA was then amplified by PCR using twenty-one primers developed by the University of British Columbia (primer set \#9). PCRs were carried out in $20 \mu \mathrm{L}$-reaction volumes containing approximately 10-50 ng of DNA, $1 \times$ PCR buffer 


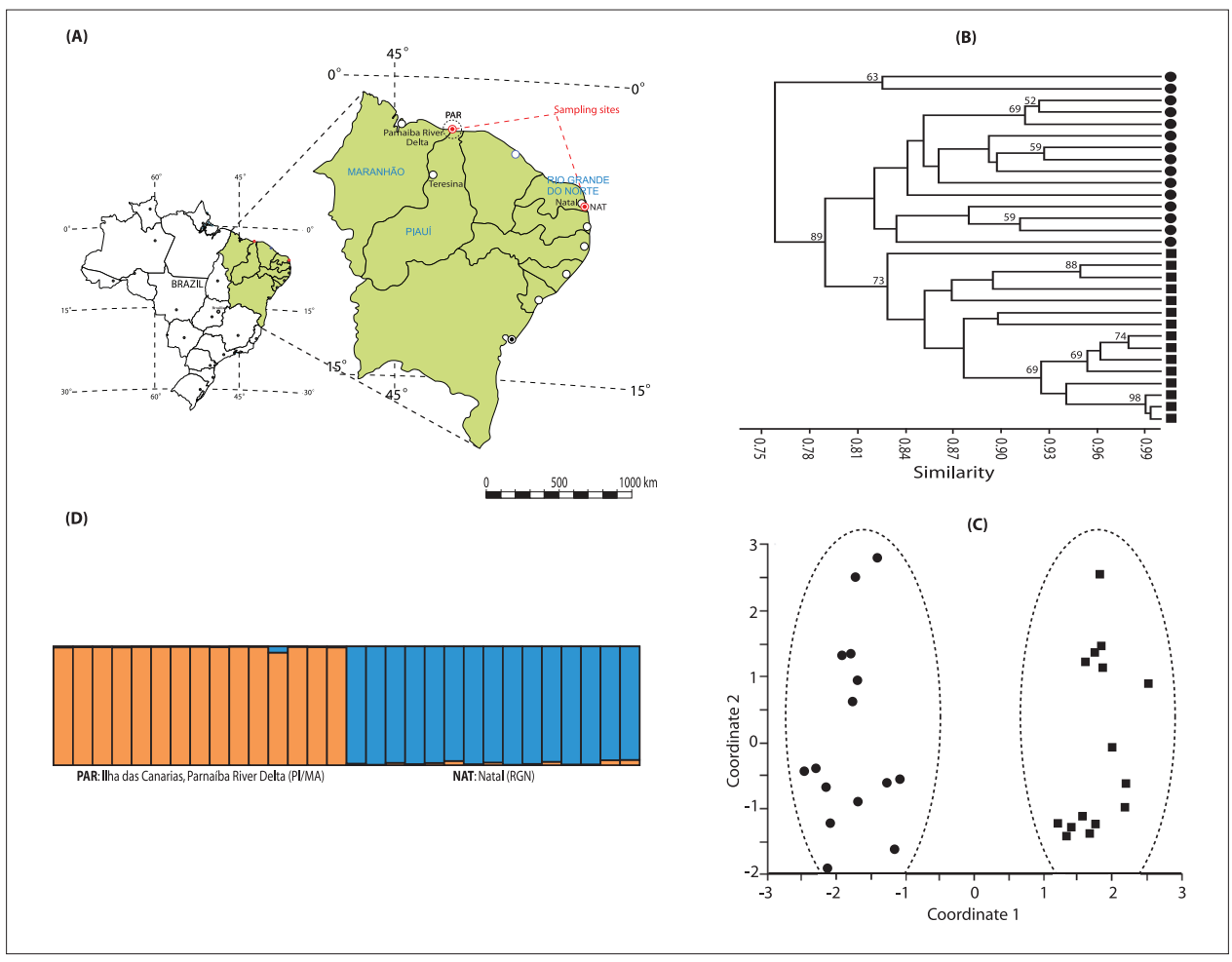

Figure I. A Sampling sites of Melipona subnitida: NAT (coordinates: $5^{\circ} 48^{\prime} 04^{\prime \prime S}, 35^{\circ} 11^{\prime} 08^{\prime \prime W}$; State

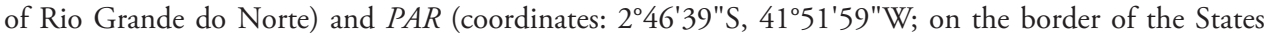
of Piauí and Maranhão) B Clustering analysis using UPGMA for M. subnitida genotypes included in this study based on DICE similarity coefficient values. Numbers indicate bootstrap values for nodes retained by more than $50 \%$ of bootstrap replicates (1000 replications) C Scatter-plot of the principal coordinate analysis (PCoA) using ISSR loci. - PAR genotypes; NAT genotypes D Bar plot from Inferred population structure of using the Bayesian grouping admixture model-based program STRUCTURE $(K=2)$.

(40 mM Tris- $\mathrm{HCl} ; 100 \mathrm{mM} \mathrm{KCl}$ ), $1.5 \mu \mathrm{M}$ of primer, $6.25 \mathrm{mM} \mathrm{MgCl}, 1.5 \mu \mathrm{M}$ of each dNTP, $1.25 \mathrm{U}$ of Invitrogen Taq DNA polymerase. All amplifications were carried out on a VERITI ${ }^{\mathrm{TM}}$ Gradient Thermalcycler (APPLIED BIOSYSTEMS). The following PCR conditions were used: an initial denaturation at $94^{\circ} \mathrm{C}$ for $1.5 \mathrm{~min}$, followed by 45 cycles of $94^{\circ} \mathrm{C} / 40 \mathrm{~s}, 36^{\circ} \mathrm{C} / 1 \mathrm{~min}$. and $72^{\circ} \mathrm{C} / 2 \mathrm{~min}$., and a final extension of $72^{\circ} \mathrm{C} / 5 \mathrm{~min}$. ISSR markers were screened by silver nitrate detection on denatured $6 \%$ polyacrylamide gels, which were scored for absence ( 0 ) and presence (1) of bands across genotypes and entered into a binary matrix.

Sample polymorphism was estimated as the percentage of polymorphic bands (PPB) in the total number of bands. The program HICKORY v.1.1, which implements the Bayesian method (Holsinger et al. 2002), was used for estimating $\theta^{\mathrm{B}}\left(\mathrm{F}_{\mathrm{ST}}\right.$ analogue), heterozygosity $\left(\mathrm{H}_{\mathrm{s}}\right)$, and the inbreeding coefficient $(f)$, an $\mathrm{F}_{\mathrm{IS}}$ analogue for dominant markers. Analysis of Molecular Variance (AMOVA) was conducted using 
all the amplified loci to check the occurrence of population structure among sampling localities using ARLEQUIN v.3.11 (Excoffier et al. 2006). The use of different algorithms for the calculation of $\mathrm{F}_{S T}$ analogues was an additional effort to check for the reliability of the data presented by ISSR markers.

Further, a Bayesian grouping admixture model (burn-in length 100,000 iteractions; run length 100,$000 ; K=1$ to 8 subpopulations tested) was used to infer the number of subpopulations (software STRUCTURE 2.3.3; Pritchard et al. 2000). These results were analyzed using STRUCTURE HARVESTERWeb v.0.6.9 (Evanno et al. 2005).

The similarity among samples within populations was estimated using PAST v1.34 (Hammer et al. 2001) according to Dice's coefficient. Cluster analysis using the unweighted pair-group method arithmetic average (UPGMA) and multidimensional principal coordinate analysis ( $\mathrm{PCoA}$ ) were performed on the data set to reveal the degree of genetic differentiation between sites.

From 21 primers initially screened for their ability to generate ISSR loci, only nine revealed consistent and polymorphic bands (loci) with 30 Jandaíra worker bees. The other 12 ISSR markers were monomorphic or had unreliable amplification and therefore are not included in the genetic diversity analysis. Polymorphic ISSR primers were also considered reproducible after repeated PCRs, under the same reaction conditions and, therefore, selected for genotyping (Table 1). PCR reactions involving these nine primers resulted in 165 loci (bands) or 18.3 bands/primer, of which 92 were polymorphic (10.2 polymorphic bands/primer) ranging in size from 250 to 1636 bp, corresponding to an average polymorphism of $57.5 \%$. Genotyping showed that most of the detected loci were polymorphic. Overall ISSR polymorphism in Melipona subnitida was similar to that of M. quadrifasciata Lepeletier (67\%) (Nascimento et al. 2010). The number of polymorphic bands per primer ranged from 5 (UBC-884 and UBC-888) to 23 (UBC-899).

ISSR genotyping revealed differences in genetic diversity based on the percentage of polymorphic bands (\% PPB), which was also estimated separately for each population. Result suggests that the NAT population $(80.7 \%)$ is characterized by a higher genetic diversity than the PAR population (64.9\%), which in theory might give the $N A T$ population an increased ability to adapt to selective pressures.

The $\theta^{\mathrm{B}}$, $f$ and $\mathrm{H}_{\mathrm{s}}$ values obtained from four different models of population structure using the Bayesian analysis are shown in Table 2. Of the models applied to the ISSR dataset, the full model, in which $\theta$ and $f$ are estimated simultaneously, was preferred primarily because of its smaller deviant information criterion (DIC) value (657.47), with a difference of more than six units required to indicate strong support over all the other models (Holsinger et al. 2002). In the Bayesian approach $\theta^{\mathrm{B}}$ (analogue to Wright's $\mathrm{F}_{\mathrm{ST}}$ ), $f$ (analogue to $\mathrm{F}_{\mathrm{IS}}$ ), and $\mathrm{H}_{\mathrm{S}}$ (average panmictic heterozygosity across populations) were estimated to be $0.33,0.31$ and 0.29 , respectively, indicating a pronounced genetic differentiation between populations, possibly caused by restricted gene flow and random genetic drift (Epperson 1995).

The analysis of molecular variance also provided additional support to the evidence of population differentiation in Melipona subnitida. The AMOVA analysis indicated 


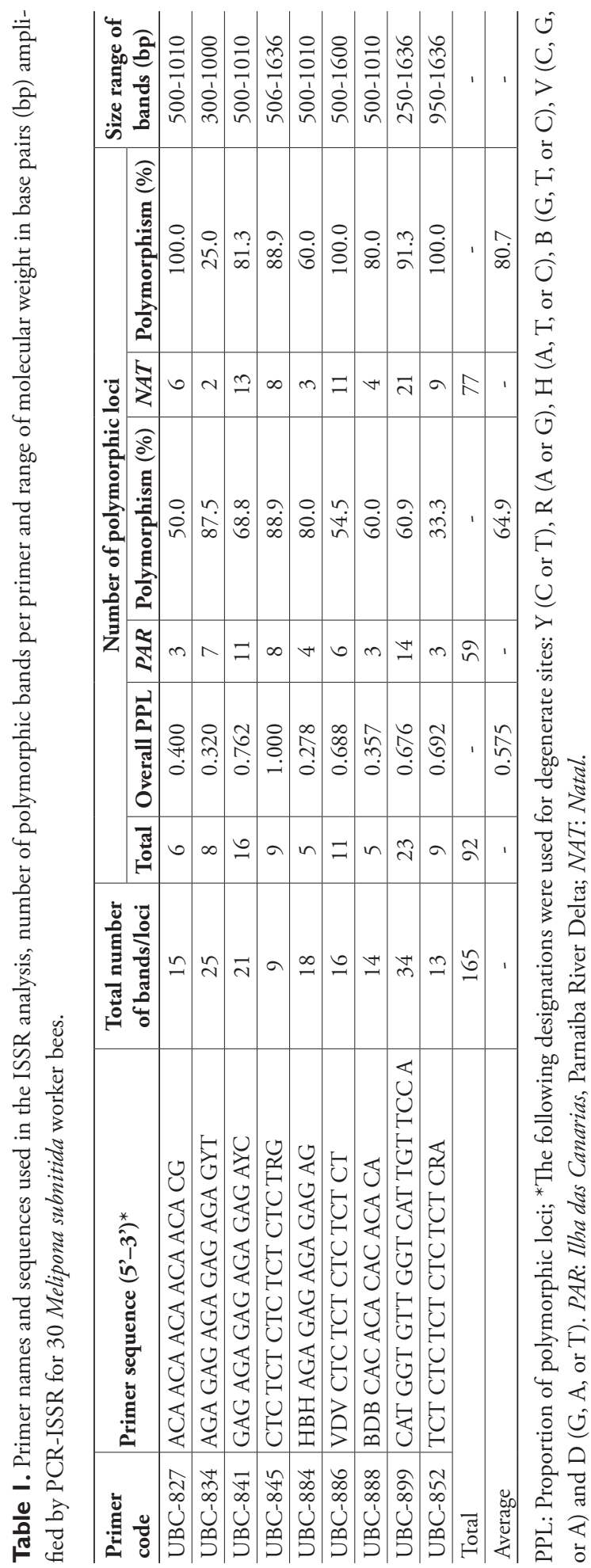


Table 2. Summary of genetic variability, partitioning of diversity and limits for credible interval by Bayesian statistical procedures.

\begin{tabular}{|c|c|c|c|c|c|c|c|c|c|c|}
\hline \multirow{2}{*}{ Models } & \multicolumn{3}{|c|}{$f$} & \multicolumn{3}{|c|}{$\theta^{\mathbf{B}}$} & \multicolumn{3}{|c|}{$\mathbf{H}_{\mathrm{s}}$} & \multirow{2}{*}{ DIC } \\
\hline & Mean & $2.5 \%$ & $97.5 \%$ & Mean & $2.5 \%$ & $97.5 \%$ & Mean & $2.5 \%$ & $97.5 \%$ & \\
\hline Full & 0.3096 & 0.0455 & 067 & 0.3275 & 0.2425 & 0.4188 & 0.2925 & 0.2565 & 0.3254 & 657.465 \\
\hline $\mathrm{f}=0$ & 0 & - & - & 0.2737 & 0.2099 & 0.3451 & 0.3272 & 0.3122 & 0.3418 & 665.837 \\
\hline$\theta^{\mathrm{B}}$ & 0.3733 & 0.1702 & 0.6037 & 0 & - & - & 0.3546 & 0.3319 & 0.3761 & 1107.250 \\
\hline$f$-free & 0.4997 & 0.0224 & 0.9742 & 0.3578 & 0.2807 & 0.4389 & 0.2771 & 0.2467 & 0.3098 & 700.287 \\
\hline
\end{tabular}

$\theta^{\mathrm{B}}$ is analogous to Wright's $\mathrm{F}_{S \mathrm{ST}}, f$ is analogous to $\mathrm{F}_{\mathrm{IS}}, \mathrm{H}_{\mathrm{S}}$ is the average panmictic heterozygosity across populations, and DIC is deviance information criterion.

Table 3. Hierarchical analysis of molecular variance (AMOVA) detected by the ISSR genotyping.

\begin{tabular}{|c|c|c|c|c|c|}
\hline Source of variation & df & Sum of squares & $\begin{array}{c}\text { Variance } \\
\text { components }\end{array}$ & $\begin{array}{l}\text { Percentage of total } \\
\text { variance }(\%)\end{array}$ & P-value* \\
\hline Among populations & 1 & 96.333 & 5.697 & 34.35 & $<0.0001$ \\
\hline $\begin{array}{l}\text { Among individuals } \\
\text { within populations }\end{array}$ & 28 & 304.800 & 10.886 & 65.65 & 0.014 \\
\hline TOTAL & 29 & 401.133 & 16.583 & & \\
\hline Fixation index & & & $\mathrm{F}_{S T}$ index & & \\
\hline
\end{tabular}

${ }^{*}$ p-values calculated from a random permutation test (10,000 permutations).

that most of the genetic variation found in $M$. subnitida samples could be attributed to differences among individuals within populations (approximately $66 \%$ of the variance), but also a large part of the variation $(34.35 \%)$ was due to differences among localities. The inbreeding coefficient $(f=0.31)$ provided by HICKORY agrees with the results obtained by the AMOVA, as moderate endogamy might be expected for strongly structured populations.

Both $\theta^{\mathrm{B}}(\mathrm{HICKORY})$ and $\Phi_{\text {ST }}$ (ARLEQUIN) presented high values, but of similar magnitude and significance $(0.33, \mathrm{p}<0.0001$ and $0.34, \mathrm{p}<0.0001$, respectively), showing that these two populations are highly structured (Tables $2-3$ ). These two different approaches showed a general agreement among the results.

A high degree of population differentiation has also been observed for Melipona quadrifasciata populations based on ISSR patterns (Nascimento et al. 2010) and M. rufiventris Lepeletier (Tavares et al. 2007) based on allozyme, microsatellite and random amplified polymorphic DNA (RAPD) molecular markers. Both studies were conducted within the State of Minas Gerais (Brazil). However, no correlation was found between the first internal transcribed spacer (ITS1) sequence divergence of $M$. subnitida populations and geographical distances in northeastern Brazil, which might be explained by the extremely high mutation rates of the ITS region in M. subnitida (Cruz et al. 2006).

Genetic differentiation within Melipona subnitida populations was probably because of low gene flow, caused by limited dispersal ability (Engels and ImperatrizFonseca 1998; Tavares et al. 2007), the large distance separating the NAT and PAR 
populations, and extensive disturbances of population dynamics due to anthropogenic habitat degradation and fragmentation (Quezada-Euan et al. 2007). More recently, mtDNA data has also pointed to genetic differentiation between these $M$. subnitida populations from Rio Grande do Norte (Mossoró city) and Piauí (Parnaíba city, on the border of Maranhão state) (Bonatti et al. 2014).

Furthermore, the dendrogram obtained by the cluster analysis (Figure 1B) and the scatter-plot of the PCoA (Figure 1C) revealed a clear separation of the species in two main clusters confirming a significant molecular genetic difference between the two populations. This topology corroborates the data presented by the Bayesian $\theta^{\mathrm{B}}$ and AMOVA. A clear evidence of subdivision among sampling sites was also observed by the Bayesian grouping model analysis of the ISSR data (Figure 1D).

This study provides additional evidence that ISSR markers can be useful tools in defining population genetic substructuring in Melipona species. More importantly, the distinctiveness of populations in these two regions suggests that the NAT and PAR populations of $M$. subnitida have separate evolutionary histories. It is clear from this study that conservation strategies should take into account the heterogeneity of these two separate populations, and that actions should be addressed towards their sustainability by integrating our findings with ecological tools. Failing to do so would risk decimating the entire bee population by uncontrolled human activities in the region.

\section{Acknowledgements}

The authors are grateful to Mr. José Maria Vieira-Neto for help in field collection. This work was supported by grants from the Northeast Bank of Brazil (BNB/ETENE/ FUNDECI) and Embrapa (Macroprograma 2, SEG Code: 02.11.01.029.00.00).

\section{References}

Abbot P (2001) Individual and population variation in invertebrates revealed by Inter-simple Sequence Repeats (ISSRs). Journal of Insect Science 1.8, 3pp. insectscience.org/1.8

Alves DFS, Cabral-Junior FC, Câmara-Cabral PPA, Oliveira-Junior RM, Rego ACM, Medeiros AC (2008) Effects of topical application of the honey of Melipona subnitida in infected wounds of rats. Revista Colégio Brasileiro de Cirurgióes 35: 88-193.

Bonatti V, Simóes ZLP, Franco FF, Francou TM (2014) Evidence of at least two evolutionary lineages in Melipona subnitida (apidae, Meliponini) suggested by mtDNA variability and geometrc morphometris of forewings. Naturwissenschaten 101: 17-24. doi: 10.1007/ s00114-013-1123-5

Camargo JMF, Pedro SEM (2013) Meliponini Lepeletier, 1836. In: Moure JS, Urban D, Melo GAR (Orgs) Catalogue of Bees (Hymenoptera, Apoidea) in the Neotropical Region - online version. http://www.moure.cria.org.br/catalogue [accessed Dec/20/2013] 
Cruz DO, Freitas BM, Silva LA, Silva SEM, Bomfim IGA (2004) Adaptação e comportamento de pastejo da abelha Jandaíra (Melipona subnitida Ducke) em ambiente protegido. Acta Scientiarum Animal Sciences 26: 293-298.

Cruz DO, Jorge DMM, Pereira JOP, Torres DC, Soares CEA, Freitas BM, Grangeiro TB (2006) Intraspecific variation in the first internal transcribed spacer (ITS1) of the nuclear ribosomal DNA in Melipona subnitida (Hymenoptera, Apidae), an endemic stingless bee from northeastern Brazil. Apidologie 37: 376-386. doi: 10.1051/apido:2006003

Engels W, Imperatriz-Fonseca VL (1998) Caste development, reproductive strategies and control of fertility in honeybees and stingless bees. In: Engels W (Ed) Social Insects. SpringerVerlag, Berlin, Germany, 167-230.

Epperson BK (1995) Spatial distributions of genotypes under isolation by distance. Genetics 140: 1431-1440.

Evanno G, Regnaut S, Goudet J (2005) Detecting the number of clusters of individuals using the software structure: a simulation study. Molecular Ecology 14: 2611-2620. doi: 10.1111/j.1365-294X.2005.02553.x

Excoffier L, Laval G, Schneider S (2006) Computational and molecular population genetics lab (CMPG). Institute of Zoology University of Berne Baltzerstrasse 63012 Bern, Switzerland.

Hammer O, Harper DAT, Ryan PD (2001) Past: Paleontological Statistics Software Package for Education and Data Analysis. Paleontology Electronic 4: 1-9.

Holsinger KE, Lewis PO, Dey DK (2002) A Bayesian approach to inferring population structure from dominant markers. Molecular Ecology 11: 1157-1164. doi: 10.1046/j.1365294X.2002.01512.x

Lima-Brito J, Castro L, Coutinho J, Morais F, Gomes L, Guedes-Pinto H, Carvalho A (2011) Genetic variability in Sambucus nigra L. clones: a preliminary molecular approach. Journal of Genetics 90: 47-52.

Michener CD (2007) The Bees of The World, 2nd ed. Johns Hopkins Univ. Press, Baltimore, MD.

Nascimento MA, Batalha-Filho H, Waldschmidt AM, Tavares MG, Campos LAO, Salomão TMF (2010) Variation and genetic structure of Melipona quadrifasciata Lepeletier. Genetic and Molecular Biology 33: 394-397. doi: 10.1590/S1415-47572010005000052

Panwar P, Nath M, Yadav VK, Kumar A (2010) Comparative evaluation of genetic diversity using RAPD, SSR and cytochrome P450 gene based markers with respect to calcium content in finger millet (Eleusine coracana L. Gaertn.). Journal of Genetics 89: 121-133. doi: 10.1007/s12041-010-0052-8

Pereira DS, Menezes PR, Filho VB, Sousa AH, Maracajá PB (2011) Abelhas indígenas criadas no Rio Grande do Norte. Acta Veterinária Brasílica 5(1): 81-91.

Pritchard JK, Stephens M, Donnelly P (2000) Inference of population structure using multilocus genotype data. Genetics 155: 945-959.

Quezada-Euan JJG, Paxton RJ, Palmer KA, Itza WJM, Tay WT, Oldroyd BP (2007) Morphological and molecular characters reveal differentiation in a Neotropical social bee, Melipona beecheii (Apidae: Meliponini). Apidologie 38: 1-12. doi: 10.1051/apido:2007006 
Rana TS, Narzary D, Ohri D (2012) Molecular differentiation of Chenopodium album complex and some related species using ISSR profiles and ITS sequences. Gene 495: 29-35. doi: 10.1016/j.gene.2011.12.031

Roulston TH, Goodell K (2011) The role of resources and risks in regulating wild bee populations. Annual Review of Entomology 56: 293-312. doi: 10.1146/annurev-ento-120709-144802

Sambrook J, Fritsch EFE, Maniatis T (1989) Molecular Cloning: A Laboratory Manual, 2nd ed. Cold Spring Harbor Lab. Press, New York, USA.

Sebastien A, Gruber MAM, Lester PJ (2012) Prevalence and genetic diversity of three bacterial endosymbionts (Wolbachia, Arsenophonus, and Rhizobiales) associated with the invasive yellow crazy ant (Anoplolepis gracilipes). Insect Sociaux 59: 33-40. doi: 10.1007/s00040011-0184-8

Silva WP, Paz JRL (2012) Abelhas sem ferrão: muito mais do que uma importância econômica. Natureza online 10: 146-152.

Tavares MG, Almeida BS, Passamani PZ, Paiva SR, Resende HC, Campos AO, Alves RMO, Waldschmidt AM (2013) Genetic variability and population structure in Melipona scutellaris (Hymenoptera: Apidae) from Bahia, Brazil, based on molecular markers. Apidologie 44: 720-728. doi: 10.1007/s13592-013-0220-y

Tavares MG, Dias LAS, Borges AA, Lopes DM, Busse AHP, Costa RG, Salomão TMF, Campos LAO (2007) Genetic divergence between populations of the stingless bee uruçu amarela (Melipona rufiventris group, Hymenoptera, Meliponini): Is there a new Melipona species in the Brazilian state of Minas Gerais? Genetics and Molecular Biology 30: 667-675. doi: $10.1590 /$ S1415-47572007000400027

Zietkiewicz E, Rafalski A, Labuda D (1994) Genome fingerprinting by simple sequence repeat (SSR) anchored polymerase chain reaction amplification. Genomics 20: 176-183. doi: 10.1006/geno.1994.1151 